Meta

Journal des traducteurs

Translators' Journal

\title{
Some Anatomical and Physiological Aspects of Medical Translation
}
Lexical equivalence, ubiquitous references and universality of subject minimize misunderstanding and maximize transfer of meaning

\section{Henry Fischbach}

Volume 31, numéro 1, mars 1986

Traduction et terminologie médicale

Medical Translation and Terminology

URI : https://id.erudit.org/iderudit/002743ar

DOI : https://doi.org/10.7202/002743ar

Aller au sommaire du numéro

Éditeur(s)

Les Presses de l'Université de Montréal

ISSN

0026-0452 (imprimé)

1492-1421 (numérique)

Découvrir la revue

Citer cet article

Fischbach, H. (1986). Some Anatomical and Physiological Aspects of Medical Translation: Lexical equivalence, ubiquitous references and universality of subject minimize misunderstanding and maximize transfer of meaning. Meta, 31(1), 16-21. https://doi.org/10.7202/002743ar
Résumé de l'article

Medical translation is the most universal and oldest field of scientific translation because of the homogeneous ubiquity of the human body (the same in Montreal, Mombasa and Manila) and the venerable history of medicine. Its terminology is mostly of Greco-Latin parentage and thus presents fewer lexicographic problems than other fields of scientific translation. A wealth of superb reference tools are readily accessible. The general miscegenation of the sciences and the extensive "lend-lease" among them require the translator to subject the source language to differential diagnosis if his translation therapy is to be successful. 


\title{
SOME ANATOMICAL AND \\ PHYSIOLOGICAL ASPECTS OF \\ MEDICAL TRANSLATION \\ LEXICAL EQUIVALENCE, UBIQUITOUS \\ REFERENCES AND UNIVERSALITY OF \\ SUBJECT MINIMIZE MISUNDERSTANDING \\ AND MAXIMIZE TRANSFER OF MEANING
}

HENRY FISCHBACH

\begin{abstract}
Medical translation is the most universal and oldest field of scientific translation because of the homogeneous ubiquity of the human body (the same in Montreal, Mombasa and Manila) and the venerable history of medicine. Its terminology is mostly of Greco-Latin parentage and thus presents fewer lexicographic problems than other fields of scientific translation. A wealth of superb reference tools are readily accessible. The general miscegenation of the sciences and the extensive "lend-lease" among them require the translator to subject the source language to differential diagnosis if his translation therapy is to be successful.
\end{abstract}

\section{INTRODUCTION}

Because medicine is one of the three oldest recorded fields of knowledge theology-philosophy and astronomy-geography being the other two - medical translation offers a triad of advantages not available to other fields of translation.

First, the subject itself - the human body and its functions - is of a universality unequalled by any other.

Second, reference sources are ubiquitous and widely accessible.

Third, the lexical equivalence, at least in the western languages, is so extensive as to border on terminological uniformity.

These three factors contribute to minimize misunderstanding and maximize meaning in the transfer of medical communication from one language to another.

Let me state at the outset that note of the above is intended to detract from the achievement of the medical translator in steering his message between the scylla of deceptive homonyms and the charybdis of parochial eponyms.

In the september 1978 issue of Meta, Dr. Anatole Sliosberg ${ }^{1}$, the eminent medical lexicographer and former president of the Société française des traducteurs, took pains to highlight some problems facing the unwary medical translator. This was a valuable service. Yet, without betraying the commitment primum non nocere, we must acknowledge our debt to the very tangible benefits accruing to us from the advantages I have listed. Many of the problems he mentions are common to all translations. Their restatement is outside the scope of this article and would merely echo Dr. Sliosberg's earlier contribution. The major thrust of this presentation is to feature the inherent aspects which tend to facilitate, rather than complicate, the medical translator's performance.

Before elaborating on these aspects, we should gain some historical perspective by briefly reviewing the early days of medicine in the light of medical translation. 


\section{HISTORY OF EARLY MEDICINE IN THE LIGHT OF TRANSLATION}

It is clear from the homeric poems that medicine already had a history, but there is no sign that it was subordinated to religion, as in ancient Egypt and India. In the "Golden Age" of Pericles, Hippocrates ( ?460- ?377 BC) - called "the Great" and later "the Father of Medicine" - became as much a representative of the Greek intellect in medicine as were his contemporaries, the great philosophers, in other fields. Some 400 years later the Hippocratic doctrine was taken up and expanded by Galen of Pergamum. The 87 treatises attributed to Hippocrates and the 100 or so still extant of Galen constituted the treasure trove of Greek medicine, the bountiful source that was to nourish several generations of medical translators. (Although none of Aristotle's writings are strictly medical, his research in anatomy and physiology contributed greatly to the progress of medicine.)

As the schools of Alexandria and Pergamum nourished Greek medical literature, this early source of medical doctrine and practice demanded translation primarily into Latin but also into Arabic and Hebrew. There is ample evidence to support the claim that Greek medicine was transplanted to Rome by translators, many of whom were physicians. Asclepaides (b. 124 BC) was the most prominent of these early Greek physicians in Rome. The whole body of medical literature from Hippocartic to Alexandrian times was summarized in Latin by Aulus Cornelius Celsus (the originator of medical Abstracting ?) in the 1st century AD. Called the "Cicero of Medicine" for his fine literay style, Celsus was also the first medical writer to translate Greek terms into Latin.

His graphic description of a surgeon's qualifications in Rome sounds positively modern :

A surgeon ought to be young, or at any rate not very old; his hands should be firm and steady, and never shake; he should be able to use his left hand with as much dexterity as his right; his eyesight should be acute and clear; his mind intrepid...2

Another prolific writer-translator of this period was Pliny the Elder, who died in 79 AD while trying to observe the eruption of Vesuvius - the one that destroyed Pompeii - at close range. Historically, it may be of interest to those with an eye for opportunities in medical translation that as late as the 3rd century $\mathrm{AD}$ - when licenses to practice medicine were introduced in Rome - Greek was still the language of instruction for medical students. The "were required to obtain good conduct certificates from the local police" (small wonder after the role physicians played in supplying the poisoned mushrooms that killed Emperor Claudius, joined the conspiracy ending the life of Drusus, and became confidential counselors to the evil Messaline); "were prohibited from joining illegal societies, visiting brothels, or taking prolonged holidays; they were expected to complete their studies before the age of twenty"3.

With the rise of Islam in the 7th century and the establishment of a united Muslim Empire in the 9th, the centers in Baghdad and Damascus boasted flourishing medical schools and the need for translation of Greek works into Arabic was paramount. One by one, the Greek medical writings, which the "heretical" Nestorians had rendered into Syriac, were now translated into Arabic, and soon Greek medicine was widely disseminated throughout the Mohammedan world. The noted contemporary medical historian and translator Martí-Ibáñez writes : "Never in history have translators played as important a part as they did at the beginning of Islamic expansion," adding that the heroes of this period were the famous Syrian and Coptic families of translators - the Bakhtishû and the Mehsues - and that "prince of translators," Hunain (known in the West as Joannitius) ${ }^{4}$, about whom more below. 
The Caliph Al-Mansur had established a school of translators in Baghdad, directed by the Christian physician Johannes Masawayh (777-857) to translate Greek manuscripts obtained in Asia Minor and Egypt. (When the debauched Byzantine emperor Michael III was defeated by Moslem forces, his penalty was to send to Baghdad a camel caravan laden with the ancient manuscripts from Constantinople's libraries. ${ }^{5}$ ) Massawayh's finest pupil was Hunain (809- 2877), a Nestorian who enriched Arabic with many scientific terms. His school translated most of the Hippocratic and Galenic writings. The most eminent physician of that day was the Persian-born Rhazes (865-925), chief of the renowned hospital in Baghdad and author of more than 140 medical tomes, many of them translated into Latin by the Hebrew scholar Faraj ben Salim. Another Persian, Avicenna (980-1037), "the Galen of Islam," composed a great encyclopedia of medical knowledge, the Canon, long regarded as a medical textbook of authority, which was often translated and used by the Latin West even as late as the 17th century. He is perhaps best remembered as the chief representative of the brilliant period of Arab medicine in Spain (10th to the 13th centuries), to which Rabbi Maimonides and other Jewish scholars greatly contributed.

After the glory of Greece has vanished and the power of Rome was destroyed, there remained only the work of these Arabic translators to bridge the gap until the rebirth of science and revival of learning at the time of the Renaissance. Many of the treatises of the major school of medical writers who flourished in the Arabic-speaking countries between the 9th and 12th centuries were translated into Latin by the Christian Gerard of Cremona (1114-1187) and the Jew Faraj ben salim - an especially fine example of the translator's art of transculturation. These translations brought about a reawakening of the European intellect and became staples of the medieval university libraries in the western world.

Early in the Middle Ages, the medical school of Salerno acquired an immense reputation (William the Conqueror visited it to restore his health) and its works were later translated into several European languages. This school is regarded as a bridge between ancient and modern medicine, more direct if less conspicuous than the circuitous route through Byzantium, Baghdad, Alexandria and Cordova by which Hippocrates and Galen reached the European world in Arabic and then Latin translation. Arab medicine itself - from Rhazes to Avidenna — was made accessible to Christian Europe by a large class of translators into Latin. It is exhilarating for today's medical translator to reflect on the prodigious cultural contribution made by our professional precursors to the advancement of medical science. This great heritage of medical translation was soon to be enriched by the advent of the printing press.

After the conquest of Toledo - where Archbishop Raymond had established a college of translators - Western scholars came into contact with the learning of the Spanish Moors, as their medical writings were translated into Latin. The Jewish scholars who were especially active in this work, often under the patronage of Christian bishops, were instrumental in founding the famous medical school in Montpellier early in the 12 th century.

In the 15 th century, as Greek scholarship made great strides, accurate translations of the Greek writers began to appear, and the humanists proposed substituting the originals of Hippocrates and Galen to lead medicine back to its sources. Since only a small body of scholars, and still fewer physicians, had a knowledge of Greek, the first task was to translate the Greeks anew into Latin. For example, there is no record that Paracelsus (?1493-1541), who lectured in his native Schwyzertütsch ${ }^{6}$, had any knowledge of Greek. (According to Daniel J. Boorstin7, Paracelsus, "the nickname by which he lived in history, ... perhaps meant that he classed himself with the great Roman 
medical authority Celsus, perhaps simply that he wrote para-doxical works that contradicted the common opinions of his profession.") the medical historians Singer and Underwood believe that "the improvement in the medical texts was due largely to the fact that more reliable translations were now available", thereby leading to a wider dissemination of the Hippocratic and Galenic writings. Among these translations were those of the humanist and physician Thomas Linacre (?1460-1524), who was instrumental in founding the Royal College of Physicians in London, taught such brilliant students as Erasmus and Thomas More, and was physician to Henry VIII.

With the colonization of the New World, many exotic plants, including ipecacuanha, cinchona and tobacco, were brought home, leading to the isolation of new drugs $^{9}$. It is of major linguistic interest to medical translation that an important serial work on these drugs by Nicolas Monardes (1493-1588) of Seville was not written in Latin, but bore the title "Historia medicinal de las cosas que se traen de nuestras Indias occidentales" and was translated into English in 1577 (by John Frampton) as "Joyfull Newes out of the Newe Founde Worlde." The vernacular languages had come into their own in medical translation.

At this milestone we must stop our brief review of early medicine in the light of translation. With this historic background we can perhaps better understand the genetics favoring medical translation with certain privileged dominant traits. The first of these, inherent in the universality of the subject, gives the medical translator an important head start.

\section{UNIVERSALITY OF SUBJECT}

This universality is self-evident since the human body and its functions - its anatomy and physiology, if you will - are the same in Montreal, Mombasa and Manila. The medical translator's task is greatly simplified by the fact that the basic anatomical and physiological elements underlying medical communication are precisely the same the world over, as are the corresponding references in both the source and target languages, even if some descriptive terms are not.

Consider how immeasurably more difficult is the task of the legal translator, who has to come to grips with juridical concepts that are not common to the source and target cultures, or that of the translator of agricultural texts, who is confronted with fauna and flora that are entirely different in the two economies.

"Ce qui se conçoit bien, s'énonce clairement", wrote Boileau in l'Art poétique, "Et les mots pour le dire arrivent aisément." There is no denying that what the translator understands well he can (usually) express clearly, but it does not follow (with all due respect to Boileau) that the words to do so will flow readily. The sameness in both languages of the object or concept to be translated certainly gives the medical translator an edge over his colleagues in other fields, thereby appreciably lowering the misconception quotient.

\section{WIDESPREAD AVAILABILITY OF DOCUMENTATION}

A second factor which tends to facilitate the medical translator's work is the widespread availability of pertinent reference material. There is hardly a major culture with a medical literature requiring translation that does not have a plethora of medical textbooks, encyclopedias, journals and dictionaries. Nor are there any medical translators who, if not physicians themselves, do not have access to a doctor or hospital librarian for ready consultation. By contrast, how many translators in aerospace, earth science or oceanography, to name but a few other scientific areas of translation, can find printed documentation or human resources with equal ease in their fields? For the medical 
translator, such animate and inanimate references are invaluable tools because of their accessibility.

Health and disease are at the very core of our existence and, on a par with religion, have preoccupied man longer and more deeply than perhaps any other concern. That is why the history of medicine is such a long and highly documented one. Few scientific achievements have been so extensively chronicled in Eastern and Western cultures. These, then are the sources which medical translation can tap again and again to enhance accuracy of terminology and aptness of idiom. Few, if any, other scientific or technical translators can mine as riche a lode of documentation.

Except for the very latest technological developments, I can conceive of no medical subject that is not discussed somewhere in the pertinent literature, and usually in fairly universal terms at that. There is less justification for hazarding terminological guesses and fewer reasons to resort to the heroic measure of coining new terms. (Word coinage is perhaps less endemic among medical translators than among others.) Except for chemistry, the available reference material is not nearly as pervasive in the other areas of translation. How easy is it, by comparison, to find or verify an elusive term in textile or printing technology ? It is self-evident that in sci-tech translation the ease with which an obscure expression can be substantiated is directly proportional to the availability of pertinent documentation.

\section{LEXICAL EQUIVALENCES}

The fact that the language of medicine, at least in the Western world, is essentially Latin and Greek, is another windfall for the medical translator. Since the dawn of recorded history, Greek and Latin - and, to an important but lesser extent, Hebrew and Arabic - have served as the languages of international communication in medicine, religion and philosophy. Broadly speaking, however, medicine (together with astronomy and geography) is the only science, as we define this term today, to have spread throughout the Western world in its original linguistic stroma. Medical terminology rests firmly on the twin pillars of Latin and Greek. The explanation for this is to be found in the history of medicine itself, as we have seen.

That the physician in ancient Greece and Rome (and, to a lesser degree, in Egypt and the Near East) should have communicated with his community in his native language is obvious. The medieval physician, however, used Latin as a means of international communication. The Belgian Vesalius and the Englishman Harvey wrote their "De Humani Corporis Fabrica" (1543) and "Exercitatio de Motu Cordis et Sanguinis" (1628), respectively, in Latin because this was the only language universally understood by all Western scientists and scholars of their day and required no translation.

Latin thus remained the language of medicine will into the 18 th century in some cases. The great work on direct percussion by the Viennese physician Leopold Avenbrugger, entitled "Inventum Novum" is dated 1761 ! By then the printing press had been introduced universally, and scientific advances in Germany, France and England led to greater popularity of the "vulgar" tongues.

Physicians, however, continued to use Latin — and still do - for record keeping and prescription writing as a way of concealing medical information from the patient. It has been claimed that "Doctors of Physick kept their secrets locked in languages their patients could not read. it is not surprising that they enjoyed the prestige of learning and the awe of the occult ${ }^{10}$." Others, concerned with medical writing, feel that the disease of "medical Latinism"11 is still endemic, regarding it as ultimately more for the purpose of international understanding "rather than for secrecy or display of knowledge ${ }^{11}$."

Today, English is beginning to replace Latin as the language of international medical communication, with such expressions as "stress, compliance, screening", etc., 
and many acronyms (viz., ACTH, SGPT, RIST, RNA) gaining acceptance everywhere... untranslated. Even so, medical terminology in both microscopic and macroscopic terms, continues to be built on pre- and suffixes of Greco-Latin parentage.

\section{MEDICAL TRANSLATION IS NOT WITHOUT ITS PROBLEM}

A reasonably identical frame of reference, relatively ubiquitous and plentiful sources of documentation, and fairly extensive lexical equivalence help the medical translator remain than much more faithful to the original text. It need not be said of him or her that, in the words of that anonymous Italian, "to translate is to betray". Today, the sci-tech translator can convincingly refute Anatole France's facile generalization, "Il y a de belles traductions, il n'y en a pas de fidèles", with which the great satirist probably meant to stigmatize literary translation.

However, nothing that has been said above should be construed to imply that there are no challenges left for the medical translator to overcome, no more problems to solve. Far from it. The general miscegenation of the sciences and the extensive "lendlease" among them has required the medical translator to expand his horizons well beyond the human body and his patrimony of Greco-Latin pre- and suffixes. Technology is an evergrowing subset - some would say superstructure - of medicine, and more than just cursory knowledge of, say, physics, chemistry, electronics and statistics is demanded for sound medical translation. These forays of other disciplines into what has, for so long, been the uniform structure of medical science have complicated the task of the medical translator, as they have that of all scientific translators.

That the medical translator can no longer rely exclusively on his knowledge of Latin and Greek, his superb medical reference books, and the relative immutability of the human body is obvious. In the graphic expression of Dr. Sliosberg ${ }^{12}$, his readers can no longer expect him to be "un homme-orchestre" - a sort of one-man band "able to play the flute and contrabassoon simultaneously and to switch indiscrimately from histology to the technology for manufacturing coated tablets or injectable ampuls". Yet, although its privileged position has been somewhat eroded by the influx of many new and strange disciplines, medical translation can still rely on a uniform subject, abundant documentation and a standardized terminology, which combine to minimize misunderstanding and maximize transfer of meaning. As an additional incentive, the medical translator can reflect with pride on a long tradition of accomplishment by our professional forebears.

Notes

1. Who shares with Henri van Hoof, Jean-Paul Coty, William Gladstone and a few others, well-deserved prominence in the world of French medical translation.

2. Martí-Ibáñez, Felix, M.D. (Ed.) (1962): The Epic of Medicine, Clarkson N. Potter, Inc., p. 87.

3. Martí-Ibáñez : op. cit., p. 90.

4. Martí-Ibáñez : op. cit., p. 118.

5. Martí-Ibáñez : op. cit., p. 127.

6. Boorstin, Daniel J. (1983) : The Discoverers - A History of Man's Search to Know His World and Himself, New York, Random House, p. 340.

7. Boorstin : op. cit., p. 339.

8. Singer, Charles and E. Ashoworth Underwood (1962) : A Short History of Medicine, New York and Oxford, Oxford University Press, p. 103.

9. Singer and Underwoord : op. cit., p. 103.

10. Boorstin, Daniel J. : op. cit., p. 338.

11. Netsky, Martin J., M.D. (1968) : "How Does the Language of Medicine Change ?" Bulletin of the American Medical Writers Association, 18 (3) : 7.

12. Sliosberg, A., M.D. (1971) : "Quelques considérations sur la traduction médicale et pharmaceutique", Babel, XVII (1) : 21. 